\title{
THE DYNAMIC OF GROWTH OF ACHIEVEMENT IN MATHEMATICS OF LATVIAN SCHOOL LEARNERS: ANALYSIS OF INTERNATIONAL RESEARCH
}

\begin{abstract}
Mathematics takes a specific place in the education of any country because the opportunities and success of youth in contemporary society are often dependent on their knowledge and skills exactly in the sphere of mathematics. Information about the status quo of mathematics education in the country is gained in international comparative research on education. The goal of the present research is to reflect the outcomes of the international project "Non-cognitive skills and Singapore learners - international comparison" organized by Singapore National Education Institute about the achievement of 2828 Latvian school learners of grade 9 in doing 12 mathematical sums. These outcomes were compared with Programme for International Student Assessment (PISA) 2003 research outcomes that, in turn, made it possible to predict the outcomes of PISA 2012 research in mathematics education as well as evaluate the efficiency of the new standard of education in Latvia in the first six years. The article will also regard the causes of the low achievement of Latvian learners in doing sums in mathematics.
\end{abstract}

Keywords: learners' achievement, mathematics education, international comparative research

\section{INTRODUCTION}

Comparative research in education constitutes an important group of education indicators that may be used to compare the systems of education in world countries that are so very different (Broks, Geske, Grīnfelds, Kangro \& Valbis, 1998), to assess the degree to which learners who are to leave primary school have mastered knowledge and skills that are needed for participation in the life of the society as well as formulate requirements for the improvement of the system of education in each country.

Two major international comparative studies may be distinguished in mathematics education: the International Association for Evaluation of Educational Achievement (IEA), international study Trends in International Mathematics and Science Study (TIMSS) and Organization for Economic Cooperation and Development (OECD) Programme for International Student Assessment (PISA). The major difference of OECD programme from research organized by IEA is found in its conceptual approach, choice of the means and methodology of research, and the age of the surveyed learners. OECD PISA research is focused on 15 years old learners and assesses the mathematical competence of learners instead of checking what learners have learned in mathematics. It must be noted that in PISA research mathematics competence is defined as individual's ability to formulate, use, interpret mathematical problems in various real life contexts. Mathematics competence includes the ability to reveal regularities by means of mathematics, use the notions, actions, and facts of mathematics to describe, explain, and predict the phenomena and their procedure (Geske, Grīnfelds, Kangro \& Kisel̦ova, 2010).

In 2003 mathematics competence of school learners in Latvia was in average slightly 
lower that that of OECD countries. In the table of mean evaluations Latvia was listed as number 27. The differences of Latvian school learners' achievement were not statistically significant from that of learners in Norway, Luxemburg, Poland, Hungary, Spain, USA, and Russia.

Competence levels are another important indicator of learners' achievement: from 1 (learners who can answer only clearly formulated questions about a familiar context that includes the respective information, can complete routine activities following clearly expressed indications in precisely formulated situations) up to 6 (learners can conceptualize, generalize, and use the information proceeding from their own investigations and complex problem situation modeling, can relate different sources of information and explanations and flexibly operate with them) (for more information see for example Geske, Grīnfelds, Kangro \& Kisel̦ova, 2010).

27 per cent of Latvian school learners could not do the sums that were more difficult that competence level 1 . No more than 3 per cent of learners reached the result that corresponds to the highest competence level 6 (Geske, Grīnfelds, Kangro \& Kiselova, 2004). However, the analysis of the mean results of PISA 2000 and PISA 2003 showed a radical improvement of the competence quality of Latvian school learners in such spheres of mathematics as space and form (geometry) and variables and functional correlations (algebra). The next PISA research took place in 2006 that showed that in the time period from 2003 to 2006 further improvement of Latvian school learners' achievement was not observed, the changes of achievement were not statistically significant (Kisel̦ova, 2011).

The results of TIMSS and PISA international research became the basis of the dialogue in the sphere of education policy in Latvia to define and implement education goals in an innovative way, to evaluate and reflect competences that learners will need in their adult life. As a result, in 2006 in basic education and in 2008 in secondary education in Latvia a new education standard was introduced including mathematics as well. The reform of the content of education marked transition from acquisition of large amount of information to competences of working with information; inclusion of contemporary topics in the content of education and emphasis on practically applicable ideas and skills; integration of the content of learning and its adjustment across academic subjects; inclusion of topics adapted to the age group of learners in the content of learning (Latvian National Standard, 2006). The new standard of mathematics of Latvia fully corresponds to the content of the mathematics link items used in PISA tests up to now; approximately a half of the standard themes are included in the PISA mathematics link items (Kiselova, 2011).

Despite the fact that for several years Latvian national standard of mathematics has fully matched the content of mathematical sums used in PISA tests until now, the analysis of the results of PISA 2009 showed that the average achievement of Latvian school learners in this period were considerably lower than those of OECD countries. Only in some European countries the achievements were worse (Greece, Romania, Bulgaria, Azerbaijan, the Balkan countries). Among all 65 member countries Latvia ranged no higher than 32-37. Comparison of competence groups revealed that there are still very few learners in Latvia whose knowledge of mathematics would correspond to the highest level of achievement (level 6 has been reached by just $1 \%$, while 5 - only by 5\% learners) (Geske, Grīnfelds, Kangro \& Kiseļova, 2010).

OECD PISA research takes place every three years and assesses learners not only in mathematics but also science, reading and problem solving, but one of the above mentioned subjects is evaluated deeper. Mathematics was in the focus of OECD research attention last time in 2003 and will be in nearest future in 2012. Therefore the evaluation of learners' achievement in 
mathematics in 2012 will yield more precise results that will also give an opportunity to evaluate the efficiency of the new education standard of Latvia after its introduction in the time of the first six years (not three as it was in PISA 2009). Yet analyzing also other comparative international studies with Latvian school learners involved, the correspondence of trends noticed by PISA 2009 to the actual situation may be tested already now.

The present research is a part of Singapore National Education Institute international

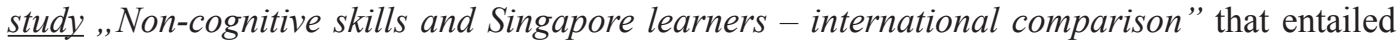
also checking learners' ability of doing mathematical sums. These outcomes were compared with Programme for International Student Assessment (PISA) 2003 and 2009 research outcomes that, in turn, made it possible to predict the outcomes of PISA 2012 research in mathematics education.

\section{THE AIM OF THE STUDY}

The following research questions were set:

1. What are the achievements of Latvian school learners in doing mathematical sums in this international study in comparison to the achievements of the learners of other countries?

2. What and how many Latvian school learner groups that cover the achievements of doing mathematical sums of similar level and structure may be distinguished according to the data acquired in the study?

3. What socio-demographical differences are there among Latvian school learners in relation to their achievements in doing mathematical sums?

\section{MATERIALS AND METHODS}

\section{Instrument}

As was stated above, the present research is a part of Singapore National Education Institute international study „Non-cognitive skills and Singapore learners - international comparison" that entailed an internet survey for learners with the aim of revealing the similar and different personality traits of learners from various countries, their attitude to mathematics, and their ability to do mathematical sums.

The present research is based just on 12 mathematical sums of the survey. All mathematical sums were multiple choice or short reply tasks and were taken from PISA or TIMSS tasks of the previous years (for more information see Table 2 in subchapter "Main results"). In their mathematical content they were from four spheres: 1) space and form, 2) variables and functional correlations, 3) numbers and measures, 4) probability, combinatorics, statistics. The sums were of different degree of complexity: tasks of reproducing (I, 5 tasks) (actions that are relatively known and that make use of the acquired knowledge and skills in practice), tasks of generalization (II, 5 tasks) (require skill of interpreting, searching for and forming a bond between different manifestations of the situation), tasks of mathematical thinking and generalization (III, 2 tasks) (require understanding of a situation and ability to generalize as well as creative approach to successful use of respective mathematical actions and knowledge) (OECD, 2004).

According to the situation and context, all tasks were distinguished into four groups: tasks of everyday life situations (entailing the context directly related to the routine actions of learners), tasks of education and vocational situations (entailing the context related to learners' life in school or at work), social context tasks (entailing situations that make learners observe some wider environment context), and science related situation tasks (entailing a more abstract context that may be related to a theoretical situation or a precisely formulated mathematical problem that has no wider context). 
For each correctly done sum learner received 1 point. If the sum had not been completed or was wrong, the learner's achievement was evaluated as 0. Exceptions are tasks 2, 7, 11. Each of those tasks contained four subtasks, therefore for doing each of these tasks learner could receive from 0 to 4 points. Hence, for a correctly done mathematical test learner could maximally score 21 points.

To assess the reliability of scale, Cronbach's Alpha coefficient was calculated for this part of survey. The value of Cronbach's Alpha was 0.582. Thus it may be concluded that reliability level of this part of survey is average and may be used in the research, though the results will not have the highest degree of probability yet. One reason for the lower reliabilities for the mathematics test is the small number of items relative to the breadth of the construct - by contrast, PISA 2003 had 85 mathematics items.

However, it was observed that if items 2 and 11 are deleted, Cronbach's Alpha grows and will reach the value 0.615 . Thus for cluster analysis only 10 items described below were used (from 1 to 12, except for 2 and 11).

\section{Sample and procedure}

From 3083 learners who participated in the research, 2828 grade 9 learners were selected from different regions in Latvia: Latgale (17 per cent), Vidzeme (13 per cent), Kurzeme (12 per cent), Zemgale (12 per cent) and Riga (46 per cent). From all participants 51.8 per cent were female and 48.2 per cent were male. 79.2 per cent studied in schools of general education, and 20.8 per cent studied in school of ethnic minorities. 43.3 per cent of all participants lived in big towns, and 56.7 per cent lived in small town or countryside (see Table 1). The learners were not selected for further research if there were mistaken data indicated, e.g., the ID number of their teacher.

Table 1. Learner sampling and researched population distribution into sociodemographical groups

\begin{tabular}{|c|c|c|c|c|}
\hline \multicolumn{2}{|c|}{ Socio-demographical indicators } & \multirow{2}{*}{$\begin{array}{c}\begin{array}{c}\text { Sampling } \\
\text { frequency } \mathbf{N}(\%)\end{array} \\
1304(46 \%) \\
482(17 \%) \\
369(13 \%) \\
327(12 \%) \\
346(12 \%)\end{array}$} & \multirow{2}{*}{$\begin{array}{c}\begin{array}{c}\text { Investigated } \\
\text { population } \\
\text { frequency (\%) }\end{array} \\
9606(43.6 \%) \\
3368(15.3 \%) \\
2777(12.6 \%) \\
3382(15.4 \%) \\
2879(13.0 \%)\end{array}$} & \multirow{2}{*}{$\begin{array}{c}\text { p value comparing the } \\
\text { investigated sampling } \\
\text { to the investigated } \\
\text { population sampling* }\end{array}$} \\
\hline $\begin{array}{l}\text { Region of } \\
\text { Latvia }\end{array}$ & $\begin{array}{c}\text { Riga and region } \\
\text { Latgale } \\
\text { Vidzeme } \\
\text { Kurzeme } \\
\text { Zemgale }\end{array}$ & & & \\
\hline Sex & $\begin{array}{l}\text { Female } \\
\text { Male }\end{array}$ & $\begin{array}{l}1464(51.8 \%) \\
1364(48.2 \%)\end{array}$ & No data & 0.060 \\
\hline $\begin{array}{l}\text { Education } \\
\text { programme }\end{array}$ & $\begin{array}{c}\text { General } \\
\text { Ethnic minority }\end{array}$ & $\begin{array}{c}2241(79.2 \%) \\
587(20.8 \%)\end{array}$ & $\begin{array}{c}16450(74.7 \%) \\
5562(25.3 \%)\end{array}$ & 0.000 \\
\hline Urbanization & $\begin{array}{c}\text { Urban } \\
\text { Rural/small town }\end{array}$ & $\begin{array}{l}1225(43.3 \%) \\
1603(56.7 \%)\end{array}$ & $\begin{array}{l}10038(45.6 \%) \\
11974(54.4 \%)\end{array}$ & 0.000 \\
\hline Birth year & $\begin{array}{c}1993 \text { or earlier } \\
1994 \\
1995 \\
1996 \text { or later }\end{array}$ & $\begin{array}{c}99(3.1 \%) \\
392(13.9 \%) \\
2248(79.5 \%) \\
97(3.4 \%)\end{array}$ & No data & \\
\hline
\end{tabular}

\footnotetext{
* Group differences were assessed with Chi-square test
} 
By means of Chi-square test it was stated that there are statistically significant differences between the sample and the investigated population. Indeed, in the surveyed population there are fewer learners from Riga region and Latgale but more from Kurzeme, and more learners live in bigger towns. To state that there are statistically significant differences between the sample and the investigated population according to sex, it was assumed that the number of boys and girls must be equal.

The data collecting process took place in November - December, 2010. Mathematics teachers who worked at that time in grade 9 were sent invitations to organize the investigation in their grade 9. Those teachers who agreed to organize the investigation were given ID number and they received instructions by e-mail.

Each learner had to fill in the questionnaire electronically either in Russian or Latvian by opening a specially created for this purpose Internet address. Therefore each learner needed a computer with Internet connection as well as some sheets of paper for draft calculations of mathematical sums. Doing the sums they were allowed to use the calculator. If learners could not cope with any of the tasks they were allowed to skip it.

Thus basically the survey was organized in computer labs and it was conducted by teacher of mathematics who gave learners instructions how to fill in the questionnaire. Each learner had to do it independently without consulting teacher or classmates, only according to one's own experience and knowledge. Though whole classes were invited to participate in the survey, it was not demanded that absolutely all learners from the particular class take part. Participation in this investigation was voluntary.

\section{MAIN RESULTS}

The following methods of statistical analysis were used for data processing: KolmogorovSmirnov test to assess the distribution of data, Descriptive Statistics, Frequencies, two step cluster analyze, hi-quadrangle criterion as well as Cronbach's Alpha to assess the reliability.

According to Kolmogorov-Smirnov criterion, the data on all items significantly differed from normal distribution, therefore the statistical analysis of differences in items was conducted using non-parametrical criterions of data analysis.

\section{Achievement of Latvian school learners and their international status}

First let us analyze the academic achievement of Latvian school learners in doing 12 mathematical sums. Tables 2 and 3 reflect the characteristic features of the mathematical sums (mathematical content, competence group, context), the source of the task and the number of learners who did/failed to do each task. Table 2 contains tasks without subtasks while table 3 includes 3 tasks with subtasks.

Summarizing the results according to the task competence content, it appeared that in average 73.5 per cent of learners failed to do tasks of competence group 1 and 47.6 per cent and 34.7 per cent from all learners scored 0 points respectively for doing tasks of competence groups 2 and 3 .

For all correctly done tasks altogether each learner who did the mathematical test could score maximally 21 points. Distributing learners' possible achievement in 7 equal intervals, the number of learners (per cent) who reached the appropriate level may be determined (see Table 4). 
Table 2. Characteristics of tasks (without subtasks) and the rate of success

\begin{tabular}{|c|c|c|c|c|c|c|c|}
\hline 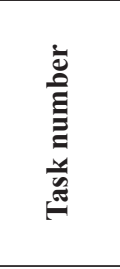 & 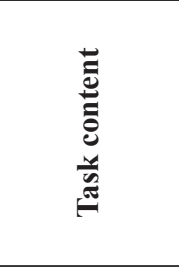 & 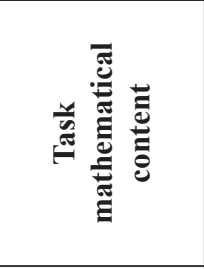 & 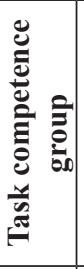 & 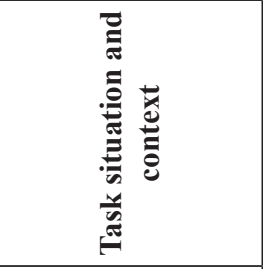 & 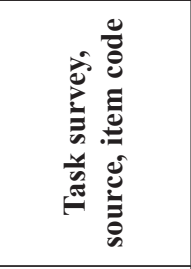 & $\begin{array}{c}\text { Number } \\
\text { of } \\
\text { learners } \\
\text { (\%) who } \\
\text { did the } \\
\text { task } \\
\text { correctly }\end{array}$ & $\begin{array}{c}\text { Number } \\
\text { of } \\
\text { learners } \\
\text { (\%) who } \\
\text { failed to } \\
\text { do the } \\
\text { task }\end{array}$ \\
\hline 1. & $\begin{array}{l}\text { Coloured } \\
\text { Candies }\end{array}$ & Probability & I & $\begin{array}{c}\text { Educational and } \\
\text { vocational situation }\end{array}$ & $\begin{array}{c}\text { PISA, 2003, } \\
\text { M467Q01 }\end{array}$ & 34.2 & 65.8 \\
\hline 3. & Bookshelves & $\begin{array}{c}\text { Numbers and } \\
\text { measures }\end{array}$ & II & $\begin{array}{c}\text { Educational and } \\
\text { vocational situation }\end{array}$ & $\begin{array}{c}\text { PISA, 2003, } \\
\text { M484Q01 }\end{array}$ & 49.9 & 50.1 \\
\hline 4. & Choices & Combinatorics & I & $\begin{array}{l}\text { Everyday life } \\
\text { situation }\end{array}$ & $\begin{array}{c}\text { PISA, 2003, } \\
\text { M510Q01 }\end{array}$ & 28.5 & 71.5 \\
\hline 5. & $\begin{array}{c}\text { Science } \\
\text { Tests }\end{array}$ & Statistics & II & $\begin{array}{c}\text { Educational and } \\
\text { vocational situation }\end{array}$ & $\begin{array}{c}\text { PISA, 2003, } \\
\text { M468Q01 }\end{array}$ & 28.9 & 71.1 \\
\hline 6. & Patio & $\begin{array}{l}\text { Numbers and } \\
\text { measures }\end{array}$ & I & $\begin{array}{c}\text { Educational and } \\
\text { vocational situation }\end{array}$ & $\begin{array}{c}\text { PISA, } \\
\text { field trial, } \\
\text { M267Q01 }\end{array}$ & 16.8 & 83.2 \\
\hline 8. & Space Flight & $\begin{array}{l}\text { Numbers and } \\
\text { measures }\end{array}$ & II & Social context & $\begin{array}{c}\text { PISA, } \\
\text { field trial, } \\
\text { M543Q01 }\end{array}$ & 45.5 & 54.5 \\
\hline 9. & Earthquake & Probability & III & Social context & $\begin{array}{c}\text { PISA, 2003, } \\
\text { M509Q01 }\end{array}$ & 41.3 & 58.7 \\
\hline 10. & Zedland & $\begin{array}{c}\text { Variables and } \\
\text { functional } \\
\text { correlations } \\
\end{array}$ & I & $\begin{array}{l}\text { Science related } \\
\text { situation }\end{array}$ & $\begin{array}{l}\text { TIMSS, 2006, } \\
\text { pg. } 106\end{array}$ & 48.6 & 51.4 \\
\hline 12. & Skateboard & Combinatorics & I & $\begin{array}{l}\text { Everyday life } \\
\text { situation }\end{array}$ & $\begin{array}{l}\text { PISA, 2003, } \\
\text { M520Q02 }\end{array}$ & 23.0 & 77.0 \\
\hline Average & & & & & & 35.2 & 64.8 \\
\hline
\end{tabular}

Table 3. Characteristics of tasks (with subtasks) and the rate of success

\begin{tabular}{|c|c|c|c|c|c|c|c|c|c|c|}
\hline \multirow{3}{*}{ 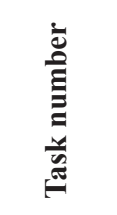 } & \multirow{3}{*}{ 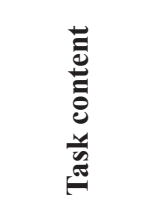 } & \multirow{3}{*}{ 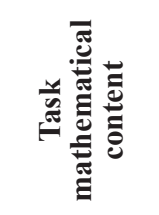 } & \multirow{3}{*}{ 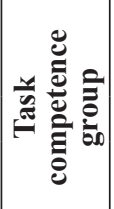 } & \multirow{3}{*}{ 总 } & \multirow{3}{*}{ 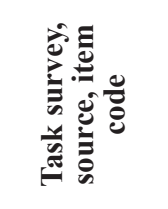 } & \multicolumn{5}{|c|}{$\begin{array}{l}\text { Number of learners who } \\
\text { scored points }(\%)\end{array}$} \\
\hline & & & & & & \multicolumn{5}{|c|}{ Points } \\
\hline & & & & & & $\mathbf{0}$ & 1 & 2 & 3 & 4 \\
\hline 2. & Carpenter & $\begin{array}{l}\text { Space and } \\
\text { form }\end{array}$ & II & $\begin{array}{c}\text { Educational } \\
\text { and vocational } \\
\text { situation }\end{array}$ & $\begin{array}{l}\text { PISA, 2000, } \\
\text { M266Q01 }\end{array}$ & 1.30 & 27.4 & 19.0 & 35.7 & 16.6 \\
\hline 7. & $\begin{array}{l}\text { Drug Con- } \\
\text { centrations }\end{array}$ & $\begin{array}{l}\text { Variables } \\
\text { and } \\
\text { functional } \\
\text { correlations }\end{array}$ & II & $\begin{array}{l}\text { Science } \\
\text { related } \\
\text { situation }\end{array}$ & $\begin{array}{l}\text { PISA, } \\
\text { field trial, } \\
\text { M307Q01 }\end{array}$ & 60.9 & 16.1 & 4.60 & 17.6 & 0.80 \\
\hline 11. & $\begin{array}{l}\text { Payment } \\
\text { by Area }\end{array}$ & $\begin{array}{l}\text { Numbers } \\
\text { and } \\
\text { measures }\end{array}$ & III & $\begin{array}{c}\text { Educational } \\
\text { and vocational } \\
\text { situation } \\
\end{array}$ & $\begin{array}{l}\text { PISA, 2003, } \\
\text { M480Q01 }\end{array}$ & 10.7 & 21.1 & 36.7 & 23.6 & 8.00 \\
\hline Average & & & & & & 24.3 & 21.5 & 20.1 & 25.6 & 8.5 \\
\hline
\end{tabular}


Table 4. The number of learners corresponding with the achievement levels of the mathematical test (\%)

\begin{tabular}{|c|c|c|c|c|c|c|c|}
\hline \multirow{2}{*}{ Quantitative indicators } & \multicolumn{7}{|c|}{ Levels of achievement } \\
\cline { 2 - 8 } & $\mathbf{0 .}$ & $\mathbf{1 .}$ & $\mathbf{2 .}$ & $\mathbf{3 .}$ & $\mathbf{4 .}$ & $\mathbf{5 .}$ & $\mathbf{6 .}$ \\
\hline $\begin{array}{c}\text { Mean coefficient of acquisition (\%) } \\
\text { and scored points }\end{array}$ & $\begin{array}{c}0-14 \\
(0-3)\end{array}$ & $\begin{array}{c}15-29 \\
(4-6)\end{array}$ & $\begin{array}{c}30-43 \\
(7-9)\end{array}$ & $\begin{array}{c}44-57 \\
(10-12)\end{array}$ & $\begin{array}{c}58-71 \\
(13-15)\end{array}$ & $\begin{array}{c}72-86 \\
(16-18)\end{array}$ & $\begin{array}{c}87-100 \\
(19-21)\end{array}$ \\
\hline $\begin{array}{c}\text { Number of learners who reached } \\
\text { the appropriate level (\%) }\end{array}$ & 4.7 & 29.3 & 34.6 & 18.1 & 8.9 & 3.7 & 0.7 \\
\hline
\end{tabular}

Judging from the learners' achievement in doing 10 mathematical sums (excluding 2 and 11), raw scale mean was calculated for each country of participants in Singapore study (Morony, Kleitman \& Stankov, 2012). Unfortunately, according to these results Latvian school learners score the lowest place among learners from all other countries, though according to PISA 2009 results the lowest achievements were demonstrated by learners from Serbia (see Table 5).

Table 5. Raw scale mean for students'achievements in Singapore Project mathematics test and PISA 2009

\begin{tabular}{|c|c|c|c|c|c|c|c|c|c|}
\hline & Singapore & Korea & $\begin{array}{c}\text { Hong } \\
\text { Kong }\end{array}$ & Taiwan & Netherlands & Denmark & Finland & Serbia & Latvia \\
\hline $\begin{array}{c}\text { Singapore } \\
\text { study (Raw } \\
\text { scale mean) }\end{array}$ & 53.91 & 50.82 & 55.87 & 50.00 & 53.12 & 47.77 & 37.55 & 37.00 & 35.02 \\
\hline $\begin{array}{c}\text { PISA 2009 } \\
\text { (Mathematics } \\
\text { Scores) }\end{array}$ & 562 & 546 & 555 & 543 & 526 & 503 & 541 & 442 & 462 \\
\hline
\end{tabular}

\section{Groups of learners}

To answer the research question about groups of learners that are equal according to the level and structure of doing mathematical sums, cluster analysis was produced. As mentioned before, only 10 items (from 1 to 12, excluding 2 and 11) were used for cluster analysis. Using two step cluster analysis, all learners, according to their results in doing 10 sums, were divided into four clusters (see Table 6).

Table 6. The number of learners (\%) who did the particular sum correctly in each cluster

\begin{tabular}{|c|c|c|c|c|c|c|c|c|c|c|c|}
\hline & \multicolumn{6}{|c|}{ Number of learners (\%) in each cluster who did the sum correctly } \\
\hline $\begin{array}{c}\text { Task No. (predictor } \\
\text { importance) }\end{array}$ & $\begin{array}{c}1 . \\
(0.64)\end{array}$ & $\begin{array}{c}3 . \\
(1.00)\end{array}$ & $\begin{array}{c}4 . \\
(0.18)\end{array}$ & $\begin{array}{c}5 . \\
(0.30)\end{array}$ & $\begin{array}{c}6 . \\
(0.34)\end{array}$ & $\begin{array}{c}7 . * \\
(0.57)\end{array}$ & $\begin{array}{c}8 . \\
(0.23)\end{array}$ & $\begin{array}{c}9 . \\
(0.14)\end{array}$ & $\begin{array}{c}10 . \\
(0.47)\end{array}$ & $\begin{array}{c}12 . \\
(0.41)\end{array}$ & Total \\
\hline $\begin{array}{c}\text { Cluster 1 } \\
\left(\mathbf{N}_{\mathbf{1}}=\mathbf{9 5 7 , 3 3 . 8 \% )}\right.\end{array}$ & 30.1 & 00.0 & 30.8 & 20.1 & 8.5 & 10.4 & 39.7 & 37.8 & 49.6 & 18.8 & $1-8$ \\
\hline $\begin{array}{c}\text { Cluster 2 } \\
\left(\mathbf{N}_{\mathbf{2}}=\mathbf{3 8 6 , 1 3 . 6 \% )}\right.\end{array}$ & 00.0 & 00.0 & 00.0 & 12.7 & 0.00 & 0.00 & 38.1 & 31.9 & 0.00 & 0.00 & $0-3$ \\
\hline $\begin{array}{c}\text { Cluster 3 } \\
\left(\mathbf{N}_{\mathbf{3}}=\mathbf{5 5 3} \mathbf{1 9 . 6} \%\right)\end{array}$ & 35.2 & 86.6 & 47.9 & 64.4 & 46.7 & 55.9 & 79.9 & 68.0 & 85.7 & 60.0 & $5-12$ \\
\hline $\begin{array}{c}\text { Cluster 4 } \\
\left(\mathbf{N}_{4}=\mathbf{9 3 2} \mathbf{3 3 . 0} \%\right)\end{array}$ & 22.1 & 100.0 & 26.4 & 23.7 & 14.6 & 12.2 & 34.2 & 32.9 & 45.7 & 14.8 & $1-8$ \\
\hline
\end{tabular}

* For Task 7 the number of learners was indicated $(\%)$ who scored 3 or 4 points for the task. 
Comparing four clusters, cluster 2 may be considered the one that unites learners with the lowest achievements because none of these learners did sums $1-4$ as well as 6,7 and 10 , and 12 , except for 5, 8, and 9. Hence, the common achievements of learners of cluster 2 will be between 0 and 3 points.

The highest achievement in doing 10 sums was demonstrated by learners of cluster 3: this cluster contains the greatest number of learners (in per cent) who did all the sums correctly (except for sum 3). The number of points scored by learners for 10 sums ranges between 5 and 12 .

The major differences between cluster 1 and 4 learners lie in the results of doing sum 3: none of the learners from cluster 1 did this sum correctly, whereas all learners of cluster 4 managed to do it (see Table 6). Besides, 67.5 per cent learners in cluster 1 scored up to 3 points for all 10 sums, while in cluster 4 the number of such learners was much smaller -45.8 per cent. The number of points scored by learners for 10 tasks in both clusters lies in the range between 1 and 8 .

\section{Socio-demographical differences of Latvian school learners in their achievement in doing mathematical sums}

By means of hi-quadrangle criterion it was made out that there are statistically significant differences $(p<0.01)$ among four clusters of learners over the regions: in cluster 3 the ratio of learners from Kurzeme and Vidzeme is much smaller and that of learners from Riga and Riga region is bigger. There are also differences according to the place of residence: in cluster 3 the majority of learners live in bigger towns (55.2 per cent), in other clusters the majority of learners live in the countryside and small towns. Especially big ratio of learners from the countryside and small towns is in cluster 2 (62 per cent).

Statistically significant differences between four clusters of learners according to the program of education and sex of learners were not located, though it must be noted that in cluster 3 the number of boys was biggest (51.5 per cent).

These results match those of the prior research on learners' achievement in mathematics in Latvia. For instance, it was stated in OECD 2003 study that school learners from Latvia living in Riga had the highest achievement as compared to learners from other regions of Latvia. The highest achievement was also registered with learners from Riga and bigger towns as compared to learners from the countryside and small towns. Achievement of girls and boys in mathematics were very similar (Geske, Grīnfelds, Kangro \& Kisel̦ova, 2004).

\section{CONCLUSIONS}

According to the analysis of learners' academic achievement in Singapore study, Latvian school learners' achievement in mathematics has not improved since 2003. For instance, in 2003 sum 12 was done by 32 per cent of all Latvian learners who participated in PISA research but the same sum in 2010 was done correctly only by 23 per cent of learners. 21 per cent of Latvian school learners in 2003 did sum 2 correctly but in 2010 it was done only by 17 per cent of learners. No doubt, there are statistically significant differences among the samplings that took part in studies in 2003 and 2010 but yet there are negative trends apparent in the dynamics of growth of Latvian school learners' achievement in mathematics (Geske, Grīnfelds, Kangro \& Kisel̦ova, 2004).

The fact that Latvian school learners' achievement has not improved since 2003 is testified to also by comparison of Latvian learners' achievement to that of other countries in Singapore study in 2010. Again it must be noted that according to these results Latvian school learners score the lowest place among all participating countries of Asia and Europe. This result matches that of PISA 2009 study, except for the fact that in 2009 the achievements of Serbian school learners were lower than those of Latvian learners (OECD, 2010). 
The number of learners who have low achievement in Singapore project test in mathematics (34 per cent having levels 0 and 1 ) greatly exceeds the number of learners who have high achievements in this test (4.4 per cent having levels 5 and 6). It must also be noted that in this research none of Latvian school learners scored the maximum number of points that, in turn, matches the trend revealed in PISA 2009 indicating the decrease of the number of outstanding learners in Latvia. For Latvia it is an important problem (Geske, Grīnfelds, Kangro \& Kisel̦ova, 2010).

It may be observed that Latvian school learners surveyed within Singapore project have not mastered some topics from education standard in mathematics. This is proved by the fact that the level of doing sums is low even for competence 1 level sums. This may be accounted for by the fact that many teachers teach topics recently added to the standard (e.g. combinatorics) only at the end of grade 9. It is possible that if this study had been produced at the end of the academic year, not in the middle, learners' achievement in it would have been much better.

Proceeding from the stated above, it may be stated that there is a high degree probability that PISA 2012 learners' achievements in mathematics will not improve and like in PISA2009 will remain lower than the average level of OECD countries. Latvian education politicians consider that PISA 2009 results bring out a serious need to analyze basic education standard in Latvia and methods of learning. However, this problem may be regarded also from other aspect. For instance, Norwegian parliament report (Norwegian Parliament, 2009) describes the teacher as the most important single factor influencing students' learning. In a review of research on teacher competence, the importance of teachers' informal competence is underlined (Nordenbo, Larsen, Tiftikci, Wendt \& Østergaard, 2008). In turn, according to many studies the process of raising teacher's competence is closely related not only to acquiring knowledge but also the formation of teacher's beliefs (Shulman, 1987; Ball, Thames \& Phelps, 2008). From various predictors who may predict learners' achievement in mathematics, the impact of teacher's beliefs on learners' achievement has been little studied so far. Clarifying this correlation between teacher's beliefs and learners' achievement may become the goal of further research.

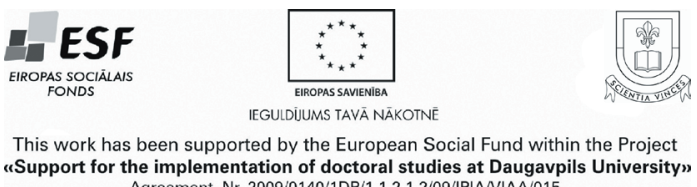
Agreement Nr. 2009/0140/1DP/1.1.2.1.2/09/IPIANIAA/015

\section{REFERENCES}

Ball, D. L., Thames, M. H., \& Phelps, G. (2008). Content knowledge for teaching: what makes it special? Journal of Teacher Education, No 59, 389-407.

Broks, A., Geske, A., Grīnfelds, A., Kangro, A., Valbis, J. (1998). Izglīīības indikatoru sistēmas [Systems of education indicators]. A. Grīnfelds, A. Kangro (red.), Monogrāfiju sērija: Izglītības pētniecība Latvijā [Series of monographs: Study of education in Latvia]. Mon. Nr. 2. Rīga: Mācību grāmata.

Geske, A., Grīnfelds, A., Kangro, A., Kiseḷova, R. (2004). Mācīšanās nākotnei. Latvija OECD valstu Starptautiskajā skolēnu novērtēšanas programmā 1998-2004. [Learning for the future. Latvia in OECD International learners' evaluation programme 1998-2004]. Rīga: Latvijas Universitāte. 
Geske, A., Grīnfelds, A., Kangro, A., Kiseļova, R. (2007). Kompetence dabaszinātnēs, matemātikā un lasīšanā - ieguldījums nākotnei. Latvija OECD valstu Starptautiskajā skolēnu novērtēšanas programmā 2006 [Competence in science, mathematics, and reading - investment in future. Latvia in OECD International learners' evaluation programme 2006]. Rīga: SIA „Drukātava”.

Geske, A., Grīnfelds, A., Kangro, A., Kisel̦ova, R. (2010). Ko skolēni zina un prot - kompetence lasīšanā, matemātikā un dabaszinātnēs. Latvija OECD valstu Starptautiskajā skolēnu novērtēěanas programmā 2009 [What learners know and can do - competence in reading, mathematics and science. Latvia in OECD International learners' evaluation programme 2009]. Rīga: Latvijas Universitāte.

Kisel̦ova, R. (2011). Latvijas pamatizglītības kvalitātes starptautiska novērtēšanas rezultāti un analīze kā informatìva bāze izglìtības vadības lèmumu pieņemšanai. Promocijas darba kopsavilkums. [Results and analysis of the international assesment of the quality of basic education of Latvia making education management decisions. Summary of the dissertation]. Retrieved 01.08.2012., from http://www.lu.lv/ fileadmin/user_upload/lu_portal/zinas/Promocijas\%20darba\%20kopsavilkums\%20Rita\%20Kiselova. pdf

Latvian National standards. (2006). Noteikumi par valsts standartu pamatizglìtībā un pamatizglìtības mācību priekšmetu standartiem. [Regulations on national standard in basic education and basic education standards of academic subjects]. Retrieved 01.08.2012., from http://www.likumi.lv/doc.php?id=150407

Morony, S., Kleitman, S., \& Stankov, L. (2012). Self-Efficacy, anexiety, self-concept and confidence as predictors of achievements in confucian and European countries. Retrieved 01. 08. 2012., from http://linguistics. byu.edu/faculty/henrichsenl/apa/APA14.html

Nordenbo, S. R., Larsen, M. S., Tiftikci, N., Wendt, R. E., \& Østergaard, S. (2008). Lcererkompetance og elevers laering $i$ barnehage og skole. Et systematisk review utført for kunnskapsdepartementet, Oslo. [Teachers 'competence and students' learning in kindergarten and School. A systematic review for the Ministry of Education, Oslo]. Dansk Clearinghouse for uddannelsesforskning. København: Danmarks Pædagogiske Universitetsforlag.

Norwegian Parliament. (2009). Stortingsmelding nr. 11 (2008-2009) [Report No. 11 (2008-2009)]. Laereren rollen og utdanningen [Teacher role and training]. Retrieved 24.08.2012., from http://www.regjeringen. no/pages/2150711/PDFS/STM200820090011000DDDPDFS.pdf

OECD. (2004). Learning for tomorrow's world - first results from PISA 2003. Paris: OECD Publishing.

OECD. (2010). PISA 2009 at a Glance. Paris: OECD Publishing.

Shulman, L. S. (1987). Knowledge and teaching: foundation of the new reform. Harvard Educational Review, No 57, 1-22.

PhD student Mg. math. Aḷesja Šapkova

Daugavpils University, the Faculty of Education and Management

Personal Address: Puškina street 7-19, Daugavpils, Latvia, LV5404

Phone: +37126103165

Fax: +37165425870

E-mail: alesja.shapkova@gmail.com 